\title{
High and low molecular weight DNA cleavage in ovarian granulosa cells: characterization and protease modulation in intact cells and in cell-free nuclear autodigestion assays
}

\author{
Alexander M. Trbovich ${ }^{1}$, Francis $\mathrm{M}$. Hughes $\mathrm{Jr}^{2}$, \\ Gloria I. Perez ${ }^{1}$, Koji Kugu ${ }^{1}$, Kim I. Tilly ${ }^{1}$, John A. Cidlowski ${ }^{2}$ \\ and Jonathan L. Tilly ${ }^{1,3}$
1 Vincent Center for Reproductive Biology, Department of Obstetrics and Gynecology, Massachusetts General Hospital/Harvard Medical School, Boston, Massachusetts 02114 USA
2 Laboratory of Integrative Biology, National Institute of Environmental Health Sciences, National Institutes of Health, Research Triangle Park, North Carolina 27709 USA
${ }^{3}$ corresponding author: Jonathan L. Tilly, Ph.D., Vincent Center for Reproductive Biology, VBK137E-GYN, Massachusetts General Hospital, 55 Fruit Street, Boston, Massachusetts 02114 USA; tel: 617724 2182; fax: 617726 7548; E-mail: tilly.jonathan@mgh.harvard.edu

Received 30.5.97; revised 10.7.97; accepted 30.7.97

Edited by D. Green

\begin{abstract}
To continue elucidation of the biochemical and molecular pathways involved in the induction of apoptosis in granulosa cells (GC) of ovarian follicles destined for atresia, we characterized the occurrence and protease modulation of high and low molecular weight (MW) DNA fragmentation during rat GC death. Atresia of ovarian follicles, occurring either spontaneously in vivo or induced in vitro, was associated with both high MW and internucleosomal (low MW) DNA cleavage. Incubation of follicles in the presence of a putative irreversible and non-competitive inhibitor of caspase-1 (interleukin-1 $\beta$-converting enzyme or ICE), sodium aurothiomalate (SAM), completely prevented internucleosomal, but not high MW, DNA cleavage. As reported previously, morphological features of apoptosis (pyknosis, cellular condensation) and atresia (granulosa cell disorganization, oocyte pseudomaturation) remained detectable in SAMtreated follicles. The potential involvement of proteases in endonuclease activation was further analyzed in cell-free assays using nuclei from both GC (which autodigest their DNA) and HeLa cells (HC, which do not autodigest their DNA unless incubated with extracts prepared from other cell types). Crude cytoplasmic extracts prepared from GC induced both high MW and internucleosomal DNA cleavage in $\mathrm{HC}$ nuclei. The induction of low, but not high, MW DNA cleavage in HC nuclei by GC extracts was suppressed by pretreatment of the extracts with SAM or with any one of the serine protease inhibitors, dichloroisocoumarin (DCl), N-tosyl-L-leucylchloromethylketone (TLCK) or N-tosyl-L-phenylchloromethylketone (TPCK). Interestingly, SAM and DCI also prevented cation-induced low MW DNA fragmentation in GC nuclei;
\end{abstract}

however, TLCK and TPCK were without effect. Our results support a role for cytoplasmic and nuclear serine proteases in the activation of the endonuclease(s) responsible for internucleosomal DNA cleavage during apoptosis.

Keywords: apoptosis; DNA cleavage; nucleases; proteases; granulosa cell; follicle; atresia; ovary

Abbreviations: GC, granulosa cell; ICE, interleukin-1 $\beta$ converting enzyme; SAM, sodium aurothiomalate; HC, HeLa cell; DCl, dichloroisocoumarin; TLCK, N-tosyl-L-leucylchloromethylketone; TPCK, N-tosyl-L-phenylchloromethylketone; IAA, iodoacetic acid; IAM, iodoacetamide; YVAD-CHO, TyrVal-Ala-Asp-aldehyde; DEVD-CHO, Asp-Glu-Val-Asp-aldehyde; PMSF, phenylmethylsulfonyl fluoride; PFGE, pulsedfield gel electrophoresis; CAGE, conventional agarose gel electrophoresis

\section{Introduction}

The vast majority of ovarian follicles formed during the perinatal period in vertebrate species undergo a process of degeneration referred to as atresia (reviewed in Tilly and Ratts, 1996). Recent investigations from a number of laboratories have identified the occurrence of apoptosis as an underlying feature of the atresia process in diverse species (Hughes and Gorospe, 1991; Tilly et al, 1991, 1992a; Tilly, 1993; Jolly et al, 1994; Guthrie et al, 1995). In most species studied thus far, apoptosis occurs predominantly in the somatic granulosa cells (GC) that support and nourish the female germ cell housed within the follicle during development. Using the rat as a model system, we and others have demonstrated that the initiation of apoptosis in GC of mature antral follicles can be modulated by gonadotrophic hormones (Tilly et al, 1992b, 1995a; Chun et al, 1994; Tilly and Tilly, 1995), locally-produced ovarian growth factors (Tilly et al, 1992b, 1995b; Chun et al, 1994; Luciano et al, 1994), neuropeptides (Flaws et al, 1995a) and cytokines (Hughes et al, 1994). Importantly, the actions of many of these factors appear to be linked to altered expression of several cell deathassociated genes (Tilly and Tilly, 1995; Tilly et al, 1995a, c; Flaws et al, 1995b; Johnson et al, 1996; reviewed in Tilly, 1996 and Tilly et al, 1997) that have been identified as key players in apoptosis regulation in non-gonadal tissues and tumour cell lines (reviewed in Reed, 1994; Korsmeyer, 1995; Wyllie, 1995; Martin and Green, 1995; Fraser and Evan, 1996; Ko and Prives, 1996; Kumar and Lavin, 1996; Patel et al, 1996; Yang and Korsmeyer, 1996).

Of direct relevance to the present study, we have reported that ovarian expression of two members of the 
cysteine aspartic acid-specific (CASP, (Alnemri et al, 1996); also referred to as ced-3/interleukin-1 $\beta$-converting enzyme (Ice)) gene family, namely CASP-2 (Ich-1 or Nedd-2; Kumar et al, 1992, 1994; Wang et al, 1994) and CASP-3 (CPP32, Yama or apopain; Fernandes-Alnemri et al, 1994; Nicholson et al, 1995; Tewari et al, 1995), are suppressed during gonadotrophin-promoted follicular survival (Flaws et al, 1995b). Additionally, proteolysis of fodrin, a cytoskeletal protein and known target for caspase attack (Martin et al, 1995, 1996), occurs during apoptosis and atresia in mouse antral follicles incubated in vitro without hormonal support (Maravei et al, 1997), and apoptosis in this model can be blocked by treatment of follicles with specific peptide inhibitors of caspases (Maravei et al, 1997). Collectively, these data suggest that caspases are involved in executing the cell death command in GC during follicular atresia, consistent with the reported role of this family of proteases in mediating apoptosis in a wide variety of extragonadal cell types (reviewed in Martin and Green, 1995; Fraser and Evan, 1996; Kumar and Lavin, 1996; Patel et al, 1996). However, we have also observed that treatment of rat ovarian follicles in culture with a reported irreversible and non-competitive inhibitor of caspase-1 (ICE), sodium aurothiomalate (SAM; Wilson et al, 1994), prevents internucleosomal DNA cleavage but not morphological indexes of apoptosis in GC (Flaws et al, 1995b). Although the basis for the dissociation of biochemical versus morphological evidence of apoptosis in ovarian follicles was not investigated, we proposed that this may be due to the occurrence of high molecular weight (MW) DNA cleavage not detected by conventional agarose gel electrophoresis (CAGE).

Recent investigations using the technique of pulsed-field gel electrophoresis (PFGE) to resolve high MW DNA fractions (greater than 20 kilobases $(\mathrm{kb})$ ) not normally distinguishable by CAGE have suggested that sequential cleavage of genomic DNA to $300 \mathrm{~kb}$ rosette structures, $50 \mathrm{~kb}$ loops and, lastly, mono- and oligonucleosomal fragments, occurs during apoptosis (reviewed in Walker and Sikorska, 1994; Walker et al, 1995). Several studies have demonstrated that morphological apoptosis can in fact proceed in the complete absence of internucleosomal DNA cleavage (Cohen et al, 1992; Collins et al, 1992; Oberhammer et al, 1993; Zakeri et al, 1993; Walker et al, 1994); however, in these examples, rosette or loop cleavage is detectable by PFGE (Walker and Sikorska, 1994). Based on these observations, we designed the present experiments to utilize PFGE and CAGE to characterize the occurrence and protease modulation of high and low MW DNA cleavage in GC of rat ovarian follicles. We then sought to compare the data obtained from analysis of intact GC (obtained in vivo and from follicles incubated in vitro as a model for atresia) to results derived from studies of DNA cleavage using previously characterized cell-free nuclear autodigestion assays. These experiments revealed that a complex interaction likely occurs between multiple proteases and nucleases during the initiation and progression of apoptosis in GC, and that different requirements for various proteases in the apoptotic response may be related to cytoplasmic versus nuclear events.

\section{Results

Analysis of DNA cleavage in GC during follicular
atresia in vivo

The first experiments were conducted to characterize high and low MW DNA cleavage in GC during apoptosis and atresia in vivo using the gonadotrophin-primed immature rat model (Hughes and Gorospe, 1991; Tilly et al, 1992b, 1995a). By PFGE analysis, cleavage of genomic DNA into high $\mathrm{MW}$ fragments migrating close to the $50 \mathrm{~kb}$ size range (DNA loops) was detectable in GC collected from unstimulated ovaries that are known to possess a large population of atretic antral follicles (Figure 1, upper panel) (Tilly et al, 1995a). The occurrence of high MW DNA cleavage in unstimulated GC was mirrored by the presence of extensive internucleosomal cleavage, as determined by CAGE and autoradiography (Figure 1, lower panel). By comparison, GC obtained from healthy antral follicles of rats primed 2 days earlier with equine chorionic gonadotrophin (eCG) did not exhibit evidence of high MW DNA breakdown nor internucleosomal DNA cleavage (Figure 1, upper and lower panels, respectively), consistent with the absence of apoptosis and atresia in gonadotrophinstimulated ovaries (Tilly et al, 1992b, 1995a).

\section{High and low MW DNA fragmentation in incubated follicles: effects of SAM in vitro}

We next determined if incubated follicles induced to undergo atresia in vitro by trophic hormone deprivation exhibit the same pattern of DNA fragmentation observed during atresia in vivo. To accomplish this, antral follicles obtained from eCGprimed ovaries were analyzed by PFGE and CAGE prior to (no apoptosis) or after a $24 \mathrm{~h}$ incubation without trophic hormone support (extensive apoptosis). It should be noted that the occurrence of apoptosis in GC of incubated rat antral follicles has been confirmed previously by morphological analysis (Flaws et al, 1995a,b). Cells within healthy follicles analyzed immediately following isolation contained only intact DNA, whereas cells within follicles incubated for $24 \mathrm{~h}$ exhibited both high and low MW DNA fragmentation (Figure 2). Consistent with our previous study (Flaws et al, 1995b), in vitro treatment of follicles with SAM did not prevent apoptosis, as defined by morphological criteria, in GC (data not shown). To determine if high MW DNA cleavage is associated with morphological features of apoptosis in GC exposed to SAM for $24 \mathrm{~h}$, follicles were analyzed by PFGE. High MW DNA cleavage was detected in both control and SAM-treated follicles incubated for $24 \mathrm{~h}$, but was absent in healthy follicles prior to culture (Figure 2, upper panel). There was no evidence of internucleosomal DNA cleavage in follicles incubated with SAM, despite the prevalence of low MW DNA fragments in follicles incubated in medium alone (Figure 2, lower panel). Thus, high MW DNA cleavage was apparently sufficient for the occurrence of morphological apoptosis in GC of SAM-treated follicles. 


\section{Analysis of protease inhibitors in HeLa cell nuclei autodigestion assays}

To further assess the potential role of proteases in endonuclease activation, we switched to a cell-free assay system using isolated HeLa cell $(\mathrm{HC})$ nuclei. In this assay, $\mathrm{HC}$ nuclei autodigest their DNA in the presence of divalent cations $\left(\mathrm{CaCl}_{2}\right.$ and $\left.\mathrm{MgCl}_{2}\right)$ only when incubated with extracts prepared from other cell types (Compton and Cidlowski, 1987; Schwartzman and Cidlowski, 1991; Hughes and

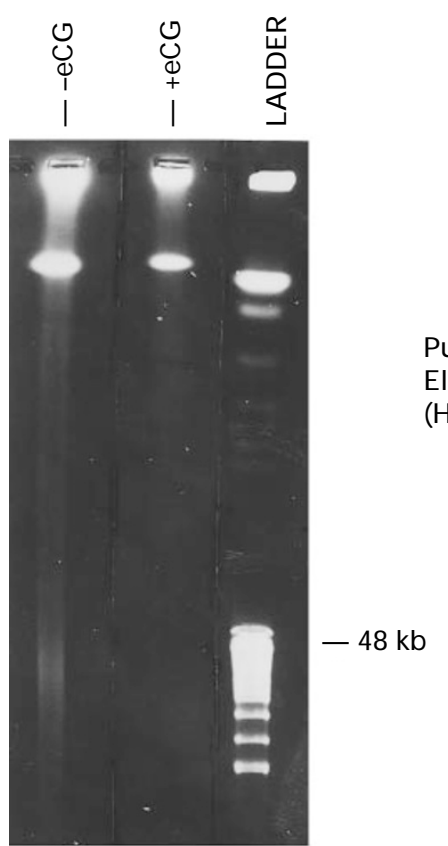

Pulsed-Field Gel Electrophoresis (High MW DNA)

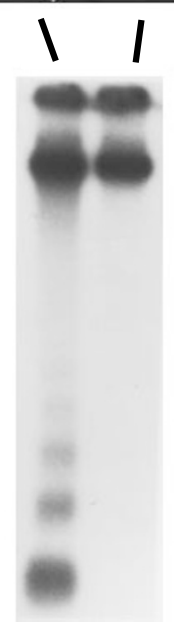

Conventional Ge Electrophoresis (Low MW DNA)
Figure 1 Analysis of high and low MW DNA cleavage in granulosa cells during atresia in vivo. Upper panel, Pulsed-field gel electrophoretic analysis of granulosa cells obtained from immature rat ovaries containing numerous atretic follicles $(-\mathrm{eCG}$ ) and from ovaries of rats primed 2 days earlier with $10 \mathrm{IU}$ of equine chorionic gonadotropin $(+\mathrm{eCG})$ to suppress apoptosis and atresia in vivo. The migration distance of a $48 \mathrm{~kb}$ DNA marker fragment (LADDER) is indicated. Lower panel, Conventional agarose gel electrophoretic analysis of the same populations of granulosa cells described in the upper panel. Note that high and low MW DNA fragments characteristic of apoptosis were only detected in granulosa cells obtained from ovaries possessing atretic follicles (see Tilly et al, 1995a)
Cidlowski, 1997). In agreement with these previous studies, crude cytoplasmic extracts prepared from GC induced both high MW and internucleosomal DNA cleavage in $\mathrm{HC}$ nuclei incubated for 120 min with $5 \mathrm{mM}$ each of $\mathrm{CaCl}_{2}$ and $\mathrm{MgCl}_{2}$ (Figures 3 and 4). Pretreatment of the GC extracts with any one of several reported protease inhibitors completely blocked (SAM; dichloroisocoumarin, $\mathrm{DCl}$ ) or partially antagonized (N-tosyl-L-leucylchloromethylketone, TLCK; N-tosyl-L-

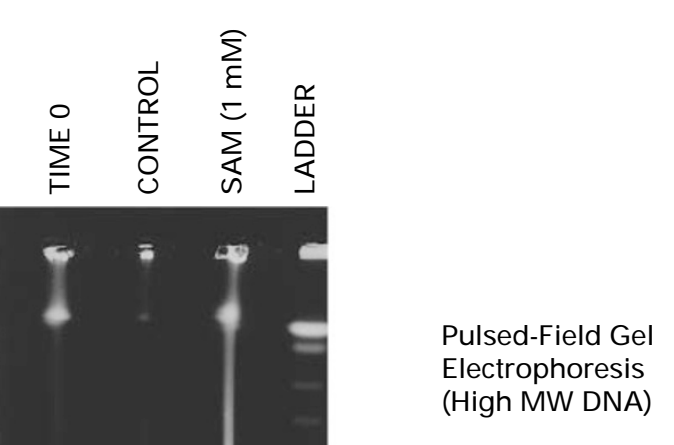

Conventional Gel Electrophoresis (Low MW DNA)

Figure 2 Analysis of high and low MW DNA cleavage in rat antral follicles incubated in vitro. Pulsed-field and conventional agarose gel electrophoretic analysis of DNA in rat follicles prior to incubation (TIME 0; healthy, no apoptosis) or following a $24 \mathrm{~h}$ serum-free incubation in the absence (CONTROL) or presence of $1 \mathrm{mM}$ sodium aurothiomalate (SAM). Both control and SAM-treated follicles exhibited extensive high MW DNA cleavage (upper panel), contrasting the complete absence of low MW DNA fragments (lower panel) in follicles treated with SAM. However, SAM-treated follicles possessed widespread apoptosis in granulosa cells, as defined by morphological criteria (data not shown; see Flaws et al, 1995b). In the upper panel, the migration distance of a $48 \mathrm{~kb}$ DNA marker fragment (LADDER) is indicated 
phenylchloromethylketone, TPCK) the ability of the cytoplasmic extract to induce internucleosomal DNA cleavage in $\mathrm{HC}$ nuclei (Figure 3, upper panel, and Figure 4). The effects of these four protease inhibitors were not mimicked by any of the eight other protease inhibitors tested (iodoacetic acid, IAA; iodoacetamide, IAM; Tyr-Val-Ala-Asp-aldehyde, YVAD-CHO; Asp-Glu-Val-Asp-aldehyde, DEVD-CHO; antipain; leupeptin; aprotinin; phenylmethylsulfonyl fluoride, PMSF) nor by the vehicles (isopropranol; dimethylsulfoxide, DMSO) used to prepare the inhibitor stocks (Figure 3, lower panel;
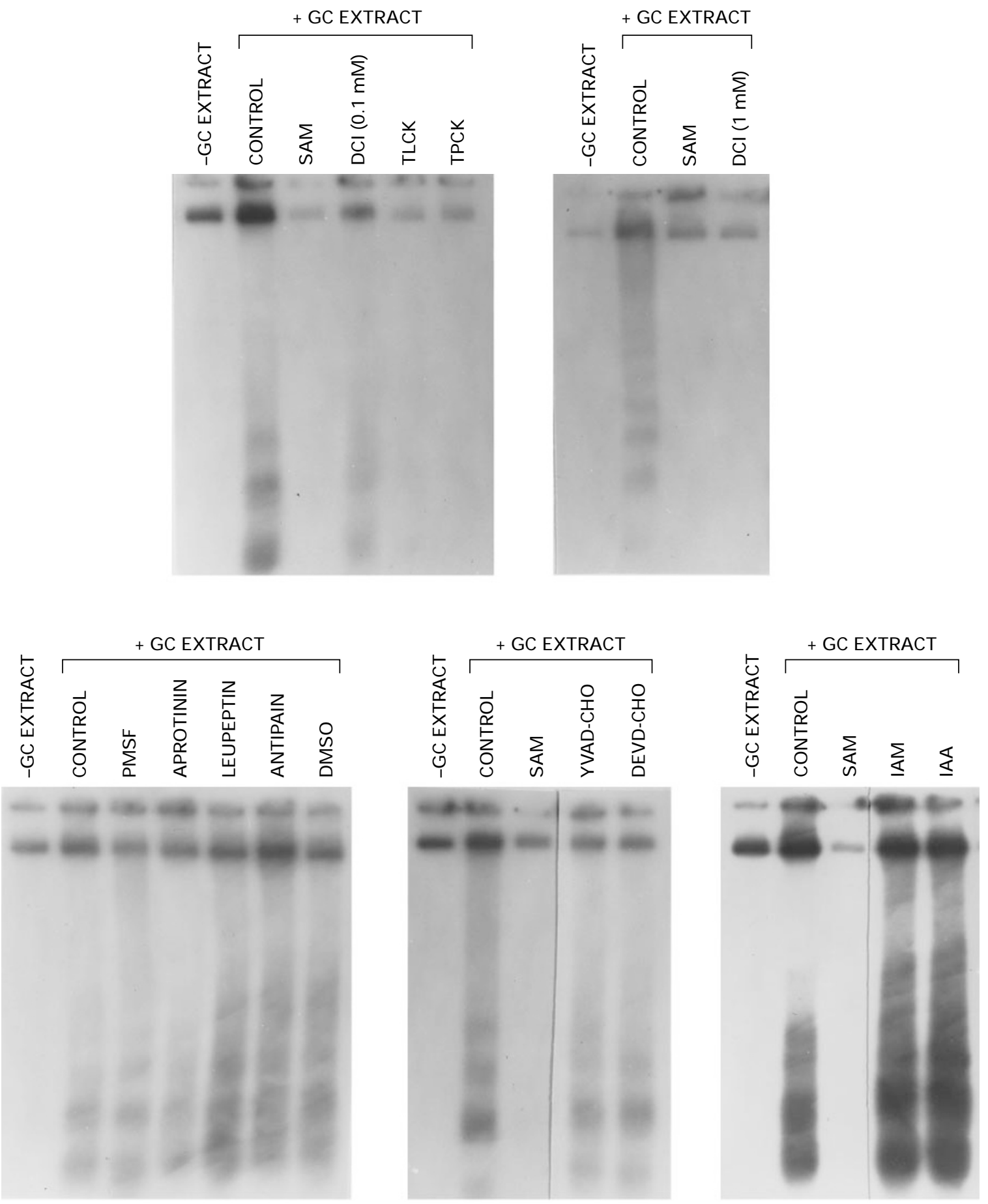

Figure 3 Qualitative analysis of low MW DNA fragmentation in HeLa cell nuclei. Nuclei isolated from HeLa cells were incubated with cations $\left(\mathrm{CaCl}_{2}\right.$ and $\mathrm{MgCl}_{2}$, $5 \mathrm{mM}$ each) in the absence (-GC EXTRACT) or presence of granulosa cell extracts (+GC EXTRACT) that had been pretreated with vehicle (CONTROL) or with one of the various protease inhibitors listed (see text for details of inhibitors and concentration used). Following incubation, DNA was extracted, quantitated, 3 '-end labeled with ${ }^{32} \mathrm{P}$-ddATP using terminal transferase ( $250 \mathrm{ng} /$ reaction), and resolved by conventional agarose gel electrophoresis. Gels were then dried and exposed to autoradiographic films to allow visualization of internucleosomal cleavage of the DNA (see Figure 4 for quantitative assessments) 


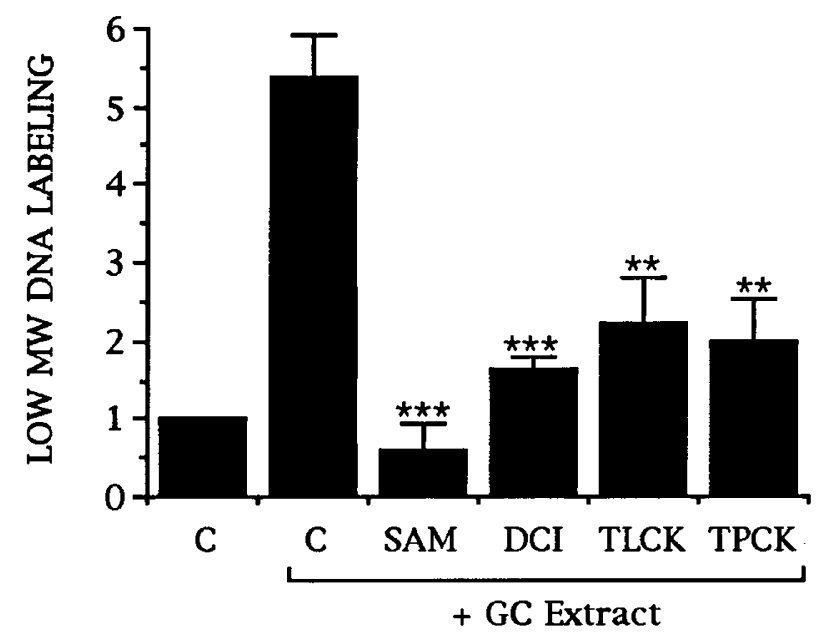

Figure 4 Quantitative analysis of low MW DNA fragmentation in HeLa cell nuclei. To provide a quantitative estimate of the effects of SAM $(1 \mathrm{mM}), \mathrm{DCl}$ $(1 \mathrm{mM})$, TLCK $(1 \mathrm{mM})$ and TPCK $(1 \mathrm{mM})$ on nuclear autodigestion using the HeLa cell nuclei assay, low MW DNA fractions $(<10 \mathrm{~kb})$ were excised from the gels depicted in Figure 3 , mixed with scintillation fluid, and analyzed by $\beta$ counting. The extent of internucleosomal DNA cleavage is directly proportional to the number of radioactive counts per sample (for details, see Tilly and Hsueh, 1993), and the data are expressed as a fold-change versus control (C) without GC extracts (this data point represents the 'background' DNA cleavage in HeLa cell nuclei), which is arbitrarily set at a value of 1 . The data represent the mean \pm S.E.M. of results from 3-5 independent experiments for each inhibitor tested ( ${ }^{* *}, P<0.01$ versus no inhibitor; ${ }^{* * *}, P<0.001$ versus no inhibitor)

quantitative data not shown). Interestingly, the occurrence of high MW DNA cleavage in HC nuclei incubated with GC extracts in the presence of divalent cations was not inhibited by SAM, DCI, TLCK or TPCK (Figure 5).

\section{Analysis of protease inhibitors in GC nuclei autodigestion assays}

Unlike HC, nuclei isolated from GC of gonadotrophinstimulated rat ovaries exhibit rapid and extensive autodigestion of DNA following incubation with $\mathrm{CaCl}_{2}$ and $\mathrm{MgCl}_{2}$ (Zeleznik et al, 1989). To extend our investigations on the effects of GC cytoplasmic extracts on HC nuclei, we next evaluated the ability of protease inhibitors to modulate divalent cation-induced autodigestion of DNA in GC nuclei. Granulosa cell nuclei incubated in the absence of $\mathrm{CaCl}_{2}$ and $\mathrm{MgCl}_{2}$ exhibited little change in DNA integrity (Figure 6). However, inclusion of $\mathrm{CaCl}_{2}$ and $\mathrm{MgCl}_{2}$ ( $5 \mathrm{mM}$ each) induced internucleosomal DNA cleavage (Figures 6 and 7) and caused extensive high MW DNA breakdown (Figure 8). Similar to results obtained with the $\mathrm{HC}$ nuclei assays, pretreatment of GC nuclei with SAM or DCl blocked the subsequent low MW DNA fragmentation elicited by addition of $\mathrm{CaCl}_{2}$ and $\mathrm{MgCl}_{2}$ (Figures 6 and 7); however, high MW DNA cleavage in GC nuclei was unaffected by the two inhibitors (Figure 8). In addition, no effect of the remaining 10 protease inhibitors (TLCK, TPCK, IAA, IAM, YVAD-CHO, DEVD-CHO, antipain, leupeptin, aprotinin, PMSF) or of the two vehicles (isopropanol, DMSO) on DNA autodigestion in GC nuclei was observed (Figure 6; quantitative data not shown).

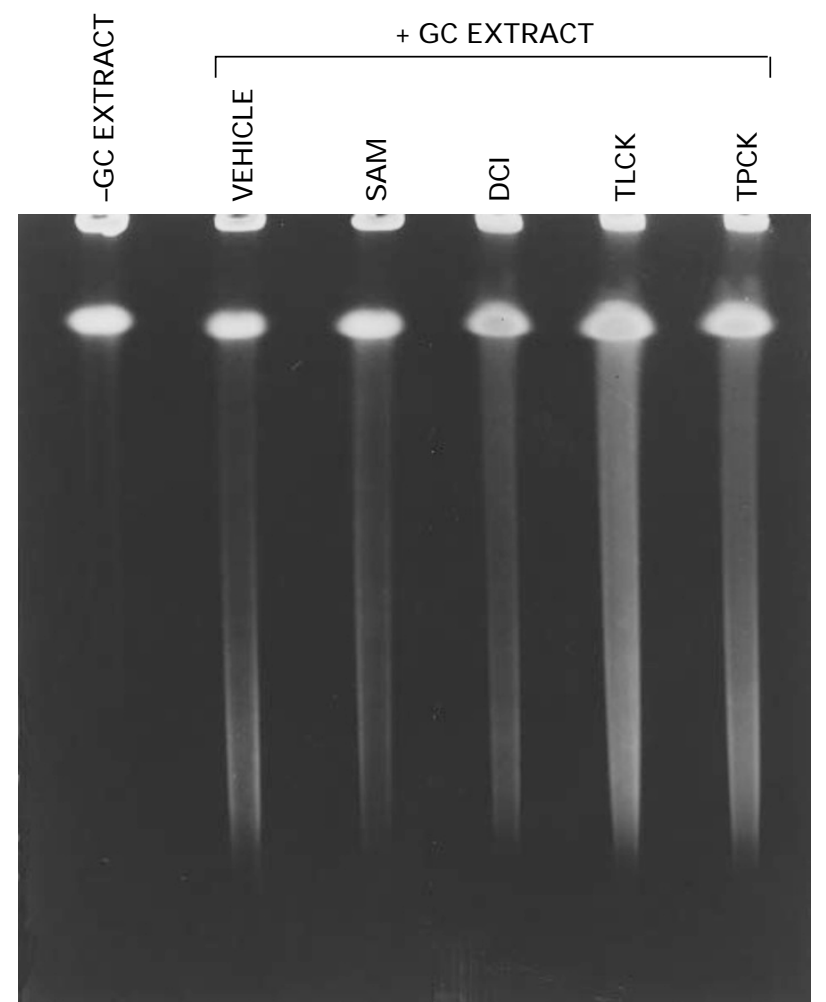

Figure 5 Pulsed-field gel electrophoretic analysis of high MW DNA cleavage in HeLa cell nuclei. Nuclei isolated from HeLa cells were incubated with cations $\left(\mathrm{CaCl}_{2}\right.$ and $\mathrm{MgCl}_{2}, 5 \mathrm{mM}$ each) in the absence (-GC EXTRACT) or presence of granulosa cell extracts (+GC EXTRACT) that had been pretreated with vehicle (CONTROL) or with $1 \mathrm{mM}$ of one of the following protease inhibitors: SAM, DCI, TLCK or TPCK. The nuclei were embedded in $0.5 \%$ agarose plugs and processsed for PFGE, after which the DNA was visualized by ethidium bromide staining and UV transillumination (see text for details)

\section{Nuclease inhibitory activity of SAM}

To determine if the ability of SAM or DCl to prevent DNA fragmentation in both cell-free assays ( $\mathrm{HC}$ and $\mathrm{GC}$ nuclei) was related to nuclease inhibition, both compounds were tested using a cell-free nuclease activity assay that relies in the ability of nuclear protein extracts to catalyze degradation of plasmid DNA (Montague et al, 1997). Granulosa cell nuclear protein extracts catalyzed degradation of the linearized plasmid DNA following a $1.5 \mathrm{~h}$ incubation with $\mathrm{CaCl}_{2}$ and $\mathrm{MgCl}_{2}$ (Figure 9). Inclusion of vehicle or $\mathrm{DCl}(0.5$ or $1 \mathrm{mM}$ ) did not affect plasmid degradation catalyzed by the GC nuclear protein extracts (Figure 9); however, SAM (1 mM) completely prevented GC nuclear protein extract-induced plasmid DNA degradation (Figure 9).

\section{Discussion}

The function of proteases, particularly the aspartate-specific cysteine proteases comprising the CASP gene family, in promoting apoptosis has become an area of tremendous research activity (reviewed in Martin and Green, 1995; Fraser and Evan, 1996; Kumar and Lavin, 1996; Patel et al, 1996). This interest stems, at least in part, from the finding that 

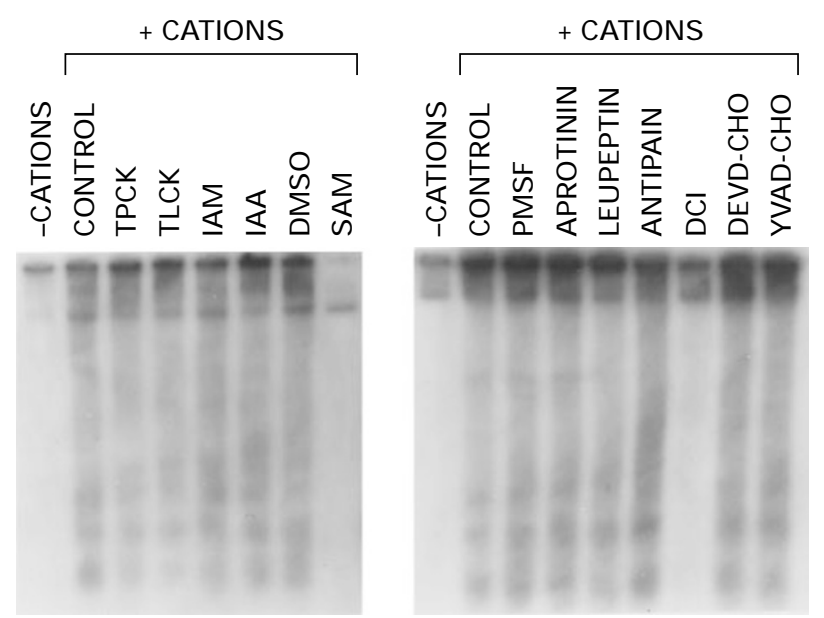

Figure 6 Qualitative analysis of low MW DNA fragmentation in granulosa cell nuclei. Biochemical analysis of DNA from granulosa cell nuclei incubated without (-CATIONS) or with (+CATIONS) $\mathrm{CaCl}_{2}$ and $\mathrm{MgCl}_{2}$ ( $5 \mathrm{mM}$ each) for $30 \mathrm{~min}$ at $37^{\circ} \mathrm{C}$ following a $15 \mathrm{~min}$ pretreatment at room temperature in the absence (CONTROL) or presence of one of 12 different protease inhibitors (see text for details). Following incubation, DNA was extracted, quantitated, 3'end labeled with ${ }^{32} \mathrm{P}$-ddATP using terminal transferase ( $250 \mathrm{ng} /$ reaction), and resolved by conventional agarose gel electrophoresis. Gels were then dried and exposed to autoradiographic films to allow visualization of internucleosomal cleavage of the DNA (see Figure 7 for quantitative assessments)

caspases represent the vertebrate counterparts to the protein encoded by the Caenorhabditis elegans death gene, ced-3 (Yuan et al, 1993; Xue et al, 1996). In elegant genetic mutation analyses conducted with the nematode, functional expression of the ced-3 gene has been demonstrated as a prerequisite event for all normal cell death to proceed during C. elegans development (Ellis and Horvitz, 1986; Hengartner and Horvitz, 1994). Moreover, recent data have indicated that caspases function downstream of Bcl-2-related proteins in a conserved intracellular pathway leading to apoptosis induction in diverse cells of vertebrate species (Chinnaiyan et al, 1996; Estoppey et al, 1997; Perry et al, 1997; Kumar, 1997), highly reminiscent of the molecular ordering of the Ced-9 death repressor protein as an upstream regulator of the Ced-3 death protease in C. elegans (Hengartner and Horvitz, 1994). Consequently, identification of the vertebrate Ced-3 homologs (caspases) is believed to be of crucial importance to our understanding of how apoptosis is modulated during normal tissue development and function in higher animal species. It should also be emphasized, however, that proteolytic enzymes not encoded by CASP gene family members, such as calpain (Squier et al, 1994) and as yet unidentified serine proteases (MacDonald and Cidlowski, 1981a,b; Suffys et al, 1988; Weaver et al, 1993; Chow et al, 1995), have also been implicated in the complex series of intracellular events leading to cell death committal.

Recently, studies of cell death in the ovary have demonstrated that apoptosis plays a fundamental role in establishment and depletion of the female germ cell reserve (Tilly, 1996; Tilly and Ratts, 1996). Furthermore, characterization of several in vivo and in vitro models for the analysis of ovarian cell demise has revealed the ovary to be extremely amenable to in-depth examination of the events
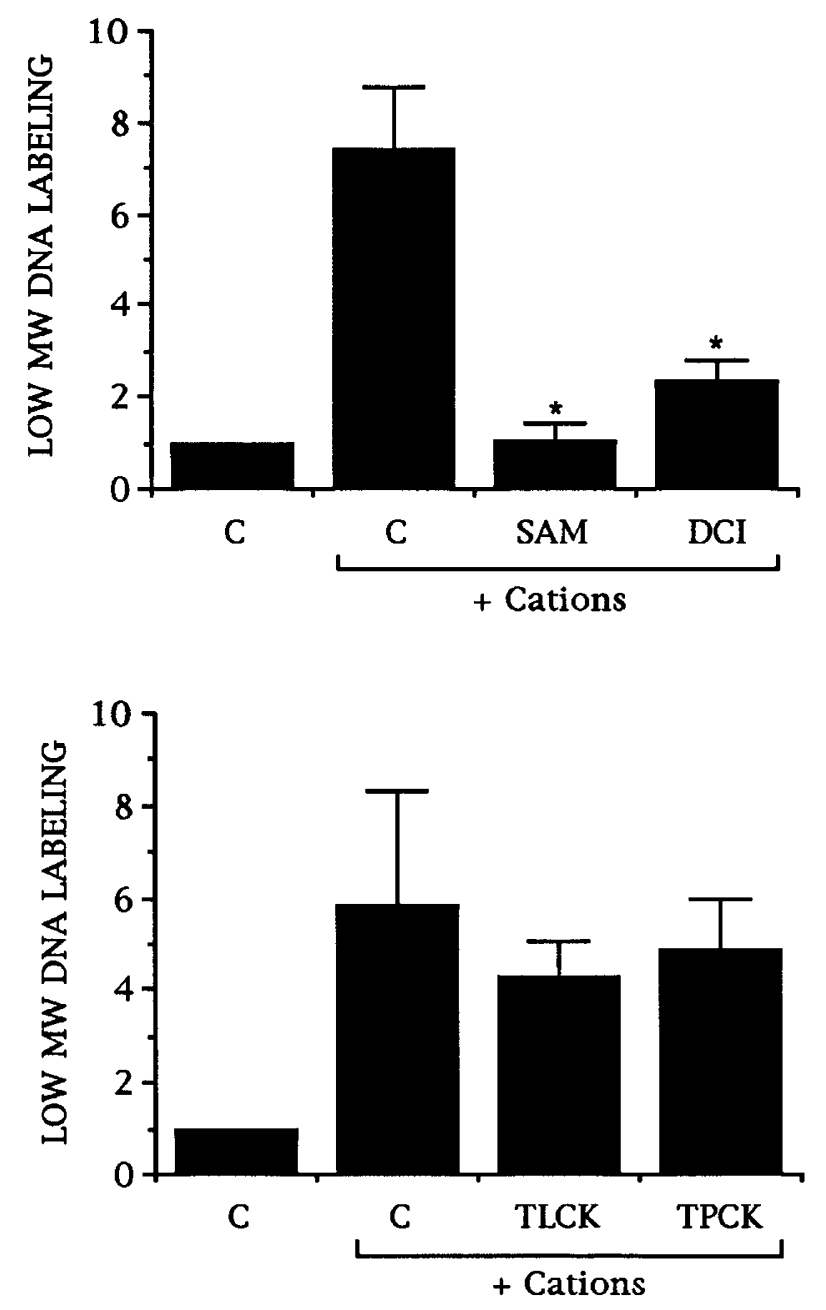

Figure 7 Quantitative analysis of low MW DNA fragmentation in granulosa cell nuclei. To provide a quantitative estimate of the effects of SAM $(1 \mathrm{mM})$, DCI (1 mM), TLCK (1 mM) and TPCK (1 mM) on nuclear autodigestion using the granulosa cell nuclei assay, low MW DNA fractions $(<10 \mathrm{~kb})$ were excised from the gels depicted in Figure 6 , mixed with scintillation fluid, and analyzed by $\beta$-counting (see legend to Figure 4 for details). The data are expressed as a fold-change versus control $(C)$ without cations (this data point represents the 'background' DNA cleavage detected in granulosa cell nuclei), which is arbitrarily set at a value of 1 . The data represent the mean + S.E.M. of results from $3-5$ independent experiments for each inhibitor tested $\left({ }^{*}, P<0.05\right.$ versus no inhibitor)

leading to apoptosis in a physiologically-relevant setting of apoptosis. Using these models, we recently provided the first evidence that members of the CASP gene family are expressed and gonadotrophin regulated in the mammalian ovary (Flaws et al, 1995b), and that proteolysis of caspase substrates (i.e., fodrin) occurs during atresia (Maravei et al, 1997). Additionally, we reported that a putative specific inhibitor of caspase-1, SAM (Wilson et al, 1994), prevented internucleosomal DNA cleavage in GC of follicles undergoing atresia. However, morphological evaluations indicated wide-spread apoptosis in GC of SAM-treated follicles despite the complete absence of low MW DNA fragmentation (Flaws et al, 1995b). As such, it was hypothesized that SAM interfered with a critical proteolytic step in the 


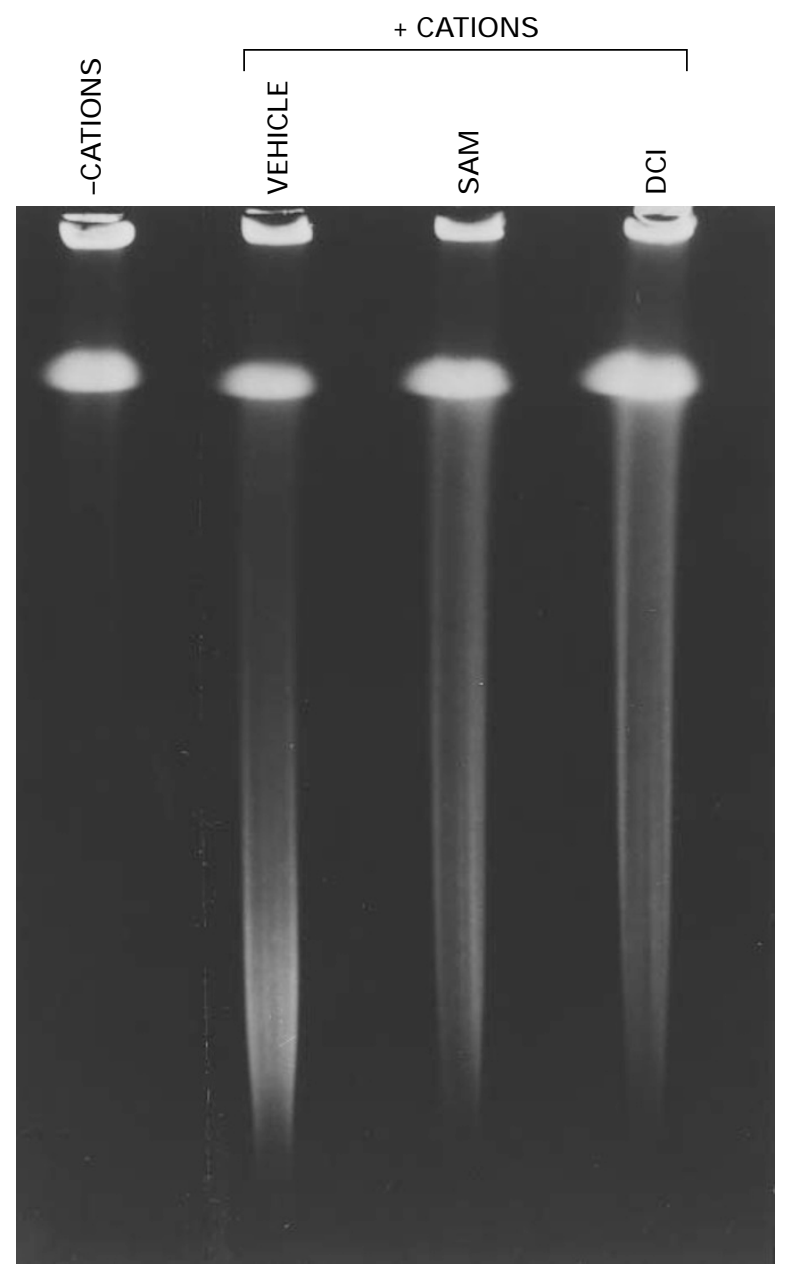

Figure 8 Pulsed-field gel electrophoretic analysis of high MW DNA cleavage in granulosa cell nuclei. Granulosa cell nuclei, incubated as described in the legend to Figure 6 without or with $1 \mathrm{mM} \mathrm{SAM}$ or DCl, were subjected to PFGE analysis. Resolved DNA was then visualized by ethidium bromide staining and UV transillumination (see text for details)

apoptotic pathway leading to mono- and oligonucleosome formation in GC.

To further clarify and extend these initial investigations, herein we characterized high and low MW DNA cleavage in GC of rat ovarian follicles during atresia in vivo and in vitro. Additionally, we explored the actions of SAM, as well as several other protease inhibitors, in the activation of nucleases responsible for high and low MW DNA fragmentation in GC. Consistent with recent studies of DNA cleavage in cells of nongonadal tissues (Cohen et al, 1992; Collins et al, 1992; Zakeri et al, 1993; Oberhammer et al,. 1993; Walker and Sikorska, 1994; Walker et al, 1995), data from the first set of experiments confirmed that high MW DNA fragments could be detected in apoptotic GC collected from atretic follicles in vivo. The relative difficulty in visualizing high MW DNA cleavage during atresia in vivo, as compared to follicles incubated in vitro, probably reflects the wide heterogeneity in the extent of apoptosis in GC of follicles at varying levels of atresia. Indeed, the unstimulated immature rat ovary possesses follicles at all stages of

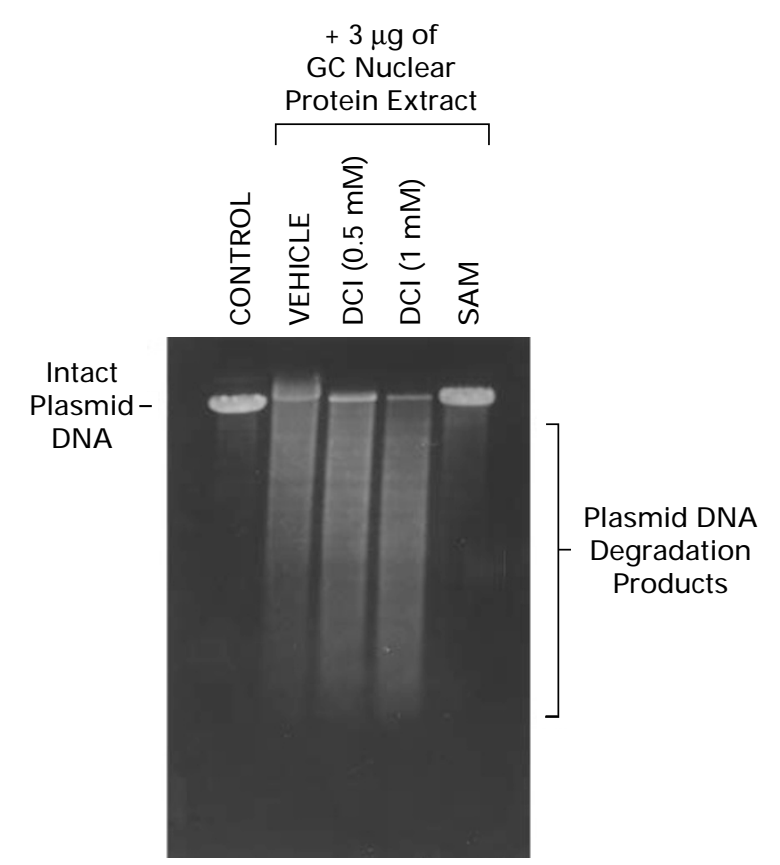

Figure 9 Analysis of nuclease inhibitory activity of SAM. Conventional gel electrophoretic analysis of pUC18 plasmid DNA integrity following incubation without (control) or with GC nuclear protein extracts in the presence of vehicle, SAM $(1 \mathrm{mM})$ or $\mathrm{DCl}(0.5$ or $1 \mathrm{mM})$. The plasmid was linearized with Smal enzyme, mixed with $3 \mu \mathrm{g}$ of $\mathrm{GC}$ nuclear protein extract in $\mathrm{Tris}-\mathrm{HCl} / \mathrm{MgCl}_{2} /$ $\mathrm{CaCl}_{2}$ buffer, and incubated at $37^{\circ} \mathrm{C}$ for $1.5 \mathrm{~h}$ (see text for details). The samples were then resolved through a $1 \%$ agarose gel, and the plasmid DNA was visualized with ethidium bromide staining and UV transillumination. Note that SAM, but not $\mathrm{DCl}$, prevented nuclease-mediated degradation of pUC18

atretic degeneration, lacking the synchrony of apoptosis induction that can be obtained by serum-free incubation of isolated follicles in vitro (Tilly et al, 1995a, 1996). Nevertheless, these data are the first to document the occurrence of high MW DNA breakdown in GC during atresia in any species, and further support the similarities in biochemical events associated with follicular atresia occurring naturally in vivo and induced in cultured follicles in vitro (Tilly et al, 1996).

The use of PFGE also enabled us to clarify a question raised in an earlier study using the putative inhibitor of caspase-1, SAM (Wilson et al, 1994), in the rat follicle culture system (Flaws et al, 1995b). Pulsed-field gel electrophoretic analysis of DNA within cells of follicles treated without and with SAM clearly revealed the occurrence of extensive high MW DNA cleavage in both follicle preparations, despite the complete absence of internucleosomal DNA cleavage in SAM-treated follicles. Based on these findings, and our earlier observations of the presence of apoptosis as assessed by morphological criteria in follicles treated with this inhibitor (Flaws et al, 1995b), we propose that high MW DNA fragmentation in the absence of internucleosomal cleavage is sufficient for apoptosis to proceed in this model system. Importantly, additional biochemical analysis of the actions of SAM, using a nuclease activity assay that minimizes any effects due to chromatin structure by employing linearized pUC18 
plasmid DNA as substrate for the nuclease(s), revealed that this compound is actually a potent nuclear inhibitor. Consequently, the ability of SAM to prevent internucleosomal DNA cleavage in GC of incubated follicles may be more reflective of its actions as a nuclease, rather than a caspase-1, inhibitor. These data also indicate that extreme caution should be exercised in the interpretation of data derived from assessing the possible role of caspases in apoptosis via the use of SAM when internucleosomal DNA cleavage serves as the sole endpoint for such analyses (Kaipia et al, 1996).

In any case, the ability of $\mathrm{DCl}$ to block autodigestion of DNA into mono- and oligonucleosomal units in both the $\mathrm{HC}$ and GC nuclei assays reinforces the concept of protease involvement in DNA degradation during apoptosis in GC. Since $\mathrm{DCl}$ is characteristically described as a highlyspecific serine protease inhibitor (Harper et al, 1985; Powers and Harper, 1986), it is likely that this, as yet unidentified, protease is not a member of the caspase family of cysteine 'death' proteases. This proposal is supported by the finding that neither of two specific and potent inhibitors of caspases, YVAD-CHO and DEVD-CHO (Thornberry et al, 1992; Wilson et al, 1994; Nicholson et al, 1995; Patel et al, 1996), were effective in modulating DNA cleavage in the GC and $\mathrm{HC}$ nuclei assays. The specificity of $\mathrm{DCl}$ action was further indicated by the relative ineffectiveness of other protease inhibitors to mimic its actions in the cell-free nuclear autodigestion experiments using GC nuclei. Included in these were the two cysteinealkylating agents, iodoacetamide and iodoacetic acid, both of which have been reported to effectively block caspasedependent proteolysis in various model systems (Thornberry et al, 1992; Miller et al, 1993; Casciola-Rosen et al, 1994; Nicholson et al, 1995; Xue et al, 1996).

The only exceptions to this finding were demonstrated by the ability of two additional serine protease inhibitors, TPCK and TLCK (Powers and Harper, 1986), to antagonize DNA cleavage in $\mathrm{HC}$ nuclei. Somewhat suprisingly, however, TLCK and TPCK were without effect in the GC nuclear autodigestion experiments. In previous studies by other investigators, the effects of DCI, TLCK and TPCK on various parameters associated with apoptosis, particularly at the level of DNA fragmentation, are somewhat controversial. For instance, preincubation of Jurkat cells with $\mathrm{DCl}$ or TPCK, but not TLCK, prevents morphological and biochemical (high and low MW DNA cleavage) aspects of apoptosis induced by activation of Fas (Weis et al, 1995). By comparison, both $\mathrm{DCl}$ and TPCK have been reported to block internucleosomal, but not high $\mathrm{MW}$, cleavage of DNA in thymocytes treated with glucocorticoids (Weaver et al, 1993). In studies that have employed a cell-free approach similar to the one used herein, the three serine protease inhibitors found to be effective in prevention of $\mathrm{GC}$ cytosol-induced genome fragmentation in $\mathrm{HC}$ nuclei (DCI, TLCK, TPCK) were also observed at comparable doses to completely $(\mathrm{DCl})$ or nearly completely (TLCK, TPCK) inhibit DNA fragmentation in HL60 nuclei exposed to cytosol prepared from HL60 cells given an apoptotic stimulus (Shimizu and Pommier, 1996). This latter study also reported that the inhibitory effects of $\mathrm{DCl}$, TLCK and
TPCK on DNA cleavage could not be replicated by leupeptin, iodoacetamide, YVAD-CHO nor DEVD-CHO, whereas PMSF was found to be only marginally effective (Shimizu and Pommier, 1996). Overall, the protease inhibitor profile for GC cytosol-induced DNA cleavage in $\mathrm{HC}$ nuclei described herein is very similar to the data obtained by Shimizu and Pommier (1996) with HL60 cell cytosol applied back to HL60 nuclei.

Although similar data were obtained, it should be pointed out that the two cell-free assays employed in our investigations were quite different than the 'homologous' cell-free approach (e.g., HL60 cytosol combined with HL60 nuclei) used by Shimizu and Pommier (1996). In the 'heterologous' HC nuclei assay, crude cytoplasmic extracts prepared from GC are believed to be the source of a protease, sensitive to inhibition by DCI, TLCK and TPCK, that is involved in catalyzing DNA digestion in $\mathrm{HC}$ nuclei. In contrast to this requirement for extracts from other cells to elicit DNA cleavage in $\mathrm{HC}$ nuclei in the presence of $\mathrm{CaCl}_{2}$ and $\mathrm{MgCl}_{2}$ (Compton and Cidlowski, 1987; Hughes and Cidlowski, 1997), nuclei prepared from GC of gonadotrophin-stimulated follicles are fully capable of DNA autodigestion when provided with only the two divalent cations (Zeleznik et al, 1989). Thus, the parallel use of these two nuclei preparations allowed us to more effectively probe the role of proteases in cytoplasmic versus nuclear events associated with DNA fragmentation. Indeed, our experiments indicate that two discrete pools of proteolytic activity involved in low MW DNA fragmentation may exist in GC, one present in the cytoplasm and sensitive to DCI, TLCK and TPCK, and another within the nuclear fraction sensitive to $\mathrm{DCl}$ only. Moreover, it is interesting to note that the extracts used for induction of DNA autodigestion in $\mathrm{HC}$ nuclei were prepared from a homogeneous pool of gonadotrophin-stimulated GC devoid of any apoptosis. These findings would argue that healthy GC maintain a fully functional, albeit quiescent, pathway of intracellular effectors ready to take part in the rapid execution of genome fragmentation during apoptosis. Although the identity of the signal(s) required to activate this pathway in GC remains to be elucidated, our findings suggest increased serine protease activity functions as one step in ensuring complete nuclear collapse during apoptosis.

\section{Materials and Methods}

\section{Chemicals and reagents}

Equine chorionic gonadotrophin (eCG or pregnant mare's serum gonadotrophin, PMSG; $2160 \mathrm{IU} / \mathrm{mg}$ ) was obtained from CalbiochemNovabiochem Corp. (La Jolla, CA, USA), and the cell culture medium and supplements were from Gibco-BRL (Gaithersburg, MD, USA). Sodium aurothiomalate was obtained from Aldrich Chemical Co. (Milwaukee, WI, USA), whereas DCI, PMSF, antipain, leupeptin, aprotinin, TLCK, TPCK, IAA and IAM were purchased from Sigma Chemical Co. (St. Louis, MO, USA). The specific caspase aldehyde inhibitors, Tyr-Val-Ala-Asp-CHO (YVAD-CHO) and Asp-Glu-Val-Asp$\mathrm{CHO}$ (DEVD-CHO), were obtained from Peptides International (Louisville, KY, USA). 


\section{Animals}

For collection of ovarian tissues, immature (25 days) female SpragueDawley rats were obtained from Charles River Laboratories (Wilmington, MA, USA), and were housed in environmentallycontrolled rooms with food and water ad libitum. Upon arrival, rats were given a single subcutaneous injection of saline (controls), or $10 \mathrm{IU}$ of eCG to promote growth of a cohort of healthy antral follicles over a subsequent $48 \mathrm{~h}$ period (Tilly et al, 1992b, 1995a). All experimental protocols involving animals were reviewed and approved by the Massachusetts General Hospital Institutional Animal Care and Use Committee. Additionally, all experiments conformed with procedures described in the $\mathrm{NIH}$ Guide for the Care and Use of Laboratory Animals.

\section{HeLa cell cultures}

For some of the cell-free nuclear autodigestion experiments, HeLa cells (ATCC CCL-2, Batch F-12477; American Type Culture Collection, Rockville, MD, USA) were cultured in Eagle's minimal essential medium (MEM) with non-essential amino acids, Earle's balanced salts solution and $10 \%$ fetal bovine serum in a humidified chamber at $37^{\circ} \mathrm{C}$ under $5 \% \quad \mathrm{CO}_{2}-95 \%$ air. Cells were harvested from the culture dishes for analysis when approximately $80 \%$ confluence was reached. Prior to collection of cells by scraping with a rubber policeman, non-adherent cells were removed by gentle washing with $2 \mathrm{ml}$ of $1 \times$ concentrated Dulbecco's phosphate-buffered saline (D-PBS). HeLa cells were selected for analysis in these experiments as previous studies have shown that $\mathrm{HC}$ nuclei do not exhibit autodigestion of DNA when incubated in the presence of calcium and magnesium, albeit both high and low MW DNA cleavage can be induced in the presence of these two divalent cations following incubation of $\mathrm{HC}$ nuclei with cellular extracts prepared from other cell types (Compton and Cidlowski, 1987; Schwartzman and Cidlowski, 1991; Hughes and Cidlowski, 1997).

\section{Granulosa cell isolation}

For analysis of high and low MW DNA integrity relative to follicular health status in vivo, GC were isolated by selective needle puncture of the 6-12 largest follicles present in ovaries of immature rats primed with saline (atretic follicles, apoptotic GC) or with gonadotrophin for 2 days (healthy follicles, non-apoptotic GC) as described (Tilly et al, 1992b, 1995a). Following estimations of cell number, aliquots of the GC were either snap-frozen for low MW DNA analysis (CAGE) or were suspended in $0.5 \%$ agarose plugs for high MW DNA analysis (PFGE). Additionally, for those experiments requiring isolation and use of GC cytoplasmic extracts and nuclei (cell-free nuclear autodigestion assays), GC were obtained by selective needle puncture of healthy antral follicles present in ovaries following 2 days of in vivo priming with eCG, as indicated above.

\section{Follicle isolation and incubation}

Healthy antral follicles between $700-800 \mu \mathrm{m}$ in diameter were isolated from ovaries of rats primed for 2 days with eCG using nonenyzmatic dissection, as detailed previously (Tilly et al, 1992b, 1995a). Briefly, the 6-10 largest follicles in each ovary were isolated using watchmaker's forceps under a dissecting microscope, and then cleaned of adherent stromal tissue and/or small follicles. Once isolated, follicles were sized for homogeneity and either snap-frozen immediately (Time 0 , no incubation) or incubated under serum-free conditions in sterile 20-ml glass scintillation vials containing $1 \mathrm{ml}$ Eagle's MEM (8 follicles/culture vial) supplemented with $0.1 \%(w: v)$ bovine serum albumin (BSA, Fraction V, fatty acid free; Sigma Chemical Co.), $2 \mathrm{mM} \mathrm{L-glutamine,} 100 \mathrm{U} / \mathrm{ml}$ penicillin and $100 \mu \mathrm{g} / \mathrm{ml}$ streptomycin sulfate for $24 \mathrm{~h}$ at $37^{\circ} \mathrm{C}$. In some treatment experiments, follicles were incubated in the absence or presence of SAM $(1 \mathrm{mM})$ for $24 \mathrm{~h}$. Following incubation, follicles were collected in $12 \times 75-\mathrm{mm}$ polypropylene tubes, snap-frozen, and stored at $-70^{\circ} \mathrm{C}$ until processed for analysis of low MW DNA integrity by $3^{\prime}$-end radiolabeling and CAGE, or were embedded in $0.5 \%$ agarose plugs for high MW DNA analysis (PFGE). For the PFGE and CAGE analyses, genomic DNA present in Time 0 follicles (no incubation) served as control data points for levels of 'background' DNA cleavage present prior to the experimental manipulations in vitro.

\section{Cell-free nuclear autodigestion assays}

Granulosa cells For each experimental replicate, nuclei were isolated from approximately $1.4 \times 10^{7} \mathrm{GC}$ (six eCG-primed ovaries) in $1 \mathrm{ml}$ of TSN buffer (10 mM Tris- $\mathrm{HCl}(\mathrm{pH} 7.4), 25 \mathrm{mM} \mathrm{NaCl}, 0.34 \mathrm{M}$ sucrose) by four strokes with a tight-fitting pestle in a Kontes glass homogenizer, followed by centrifugation at $800 \times g$ for $10 \mathrm{~min}$ at $4^{\circ} \mathrm{C}$. The crude cytoplasmic extract (supernatant) was collected to a $1.5 \mathrm{ml}$ tube and stored on ice (for subsequent use in the $\mathrm{HC}$ nuclear autodigestion assay; see below), whereas the resultant nuclear pellet was gently resuspended in $1.4 \mathrm{ml}$ of TSN buffer. Aliquots of the resuspended nuclei $(100 \mu \mathrm{l})$ were dispensed into $1.5 \mathrm{ml}$ tubes, and then preincubated with $1 \mu \mathrm{l}$ of vehicle (TSN buffer, DMSO or isopropanol), SAM (1 mM final), $\mathrm{DCl}(0.1$ or $1 \mathrm{mM}$ final), TLCK (1 mM final), TPCK (1 mM final), YVAD-CHO (100 $\mu \mathrm{M}$ final), DEVDCHO (100 $\mu \mathrm{M}$ final), IAA (1 mM final), IAM (1 mM final), PMSF (1 mM final), antipain ( $1 \mathrm{mM}$ final), aprotinin $(1 \mu \mathrm{g} / \mathrm{ml}$ final) or leupeptin $(1 \mu \mathrm{g} /$ $\mathrm{ml}$ final) for $15 \mathrm{~min}$ at $20^{\circ} \mathrm{C}$. An equal volume $(101 \mu \mathrm{l})$ of $10 \mathrm{mM}$ Tris$\mathrm{HCl}\left(\mathrm{pH}\right.$ 7.4) or $\mathrm{CaCl}_{2} / \mathrm{MgCl}_{2}$ (10 mM each in $10 \mathrm{mM}$ Tris- $\mathrm{HCl}, \mathrm{pH} 7.4$; $5 \mathrm{mM}$ each final for the autodigestion assay) was then added to the nuclei suspensions. Incubations for GC nuclear autodigestion were carried out at $37^{\circ} \mathrm{C}$ for $30 \mathrm{~min}$ (Zeleznik et al, 1989) after which nuclei were pelleted by centrifugation $\left(5 \mathrm{~min}, 4^{\circ} \mathrm{C} 800 \times g\right)$. The supernatants were removed and discarded, and the pellets were either snap-frozen for CAGE or resuspended in $50 \mu \mathrm{l}$ of pre-warmed $\left(37^{\circ} \mathrm{C}\right) 0.5 \%$ agarose for PFGE. Nuclei not incubated served as Time 0 data points for both assays.

HeLa cells For each experimental replicate, approximately $7.5 \times 10^{6}$ $\mathrm{HC}$ were homogenized in $2 \mathrm{ml}$ of TSN as indicated above, and nuclei were collected by centrifugation $\left(10 \mathrm{~min}, 4^{\circ} \mathrm{C}, 800 \times g\right)$. Supernatants were discarded and the nuclear pellet was resuspended in $1 \mathrm{ml}$ of $10 \mathrm{mM}$ Tris- $\mathrm{HCl}\left(\mathrm{pH}\right.$ 7.4) containing $10 \mathrm{mM}$ each of $\mathrm{CaCl}_{2}$ and $\mathrm{MgCl}_{2}$. Aliquots $(100 \mu \mathrm{l})$ of the $\mathrm{HC}$ nuclei were dispensed into $1.5 \mathrm{ml}$ tubes, and then mixed with $100 \mu \mathrm{l}$ of TSN buffer or $100 \mu \mathrm{l}$ of GC cytoplasmic extract (equivalent to cytoplasmic extract from $10^{6}$ cells) that had been preincubated without or with protease inhibitors (see previous section) for $15 \mathrm{~min}$ at $20^{\circ} \mathrm{C}$. HeLa nuclei were then incubated at $37^{\circ} \mathrm{C}$ for $120 \mathrm{~min}$ (Casciola-Rosen et al, 1994), after which nuclei and supernatant were separated by centrifugation $\left(5 \mathrm{~min}, 4^{\circ} \mathrm{C}, 800 \times \mathrm{g}\right)$. The supernatant was discarded, and the nuclear pellet was either snap-frozen for CAGE or resuspended in $50 \mu \mathrm{l}$ of pre-warmed $\left(37^{\circ} \mathrm{C}\right)$ $0.5 \%$ agarose for PFGE. Nuclei not incubated served as Time 0 data points for both assays. Granulosa cell cytoplasmic extract without HC nuclei served as a second control to ensure there was no nuclear DNA contribution from the homogenized GC to the $\mathrm{HC}$ nuclear autodigestion assay. 


\section{Pulsed-field gel electrophoresis (PFGE)}

Follicles, cells or nuclei were embedded in agarose plugs $(50 \mu$ total volume, $0.5 \%$ final), and immediately immersed in $10 \mathrm{ml}$ of PFGE lysis buffer (100 mM EDTA, 1\% N-lauroyl-sarcosine) for overnight incubation at $37^{\circ} \mathrm{C}$. Plugs were then removed, immersed in $1 \mathrm{ml}$ of PFGE lysis buffer containing $50 \mu \mathrm{g} / \mathrm{ml}$ of proteinase- $\mathrm{K}$ and incubated at $50^{\circ} \mathrm{C}$ for an additional $12 \mathrm{~h}$. Following proteolytic digestion, plugs were pre-equilibrated in $0.5 \times$ TBE $(0.89 \mathrm{M}$ Tris- $\mathrm{HCl}, 0.89 \mathrm{M}$ boric acid, $2.5 \mathrm{mM}$ EDTA) for at least $3 \mathrm{~h}$, and then subjected to PFGE using a clamped homogeneous electric field (CHEF) pulsed-field system (BioRad Laboratories, Hercules, CA, USA) for $19 \mathrm{~h}$ at $14^{\circ} \mathrm{C}$ and $6 \mathrm{~V} / \mathrm{cm}$ with a linear switch interval ramp from 0.5 to $45 \mathrm{~s}$. These parameters were chosen to optimally separate DNA fragments ranging from 10$500 \mathrm{~kb}$ in a linear fashion (Birren and Lai, 1993; Hughes and Cidlowski, 1997). Size standards included chromosomes from $S$. cerevisiae and 8-48 kb DNA standards provided by Bio-Rad. Following PFGE, DNA was visualized by ethidium bromide staining and UV transillumination.

\section{Autoradiographic analysis of internucleosomal DNA cleavage following CAGE}

Genomic DNA was prepared from intact follicles or isolated nuclei as described (Gross-Bellard et al, 1973) and modified (Tilly and Hsueh, 1993). The quantity and purity of the DNA preparations were estimated by spectrophotometric measurements of the optical density of each sample at 260 versus $280 \mathrm{~nm}$. Following isolation and quantitation, DNA samples ( $1 \mu \mathrm{g} /$ reaction) were $3^{\prime}$-end labeled with $\left[\alpha^{32} \mathrm{P}\right]$-dideoxyATP $(3000 \mathrm{Ci} / \mathrm{mmol}$; Amersham, Arlington Heights, IL, USA) using the terminal transferase reaction (Boehringer-Mannheim, Indianapolis, IN, USA), fractionated through conventional $2 \%$ agarose gels, and then analyzed by autoradiography and $\beta$-counting of low MW $(<10 \mathrm{~kb})$ DNA fragments, as described (Tilly and Hsueh, 1993; Tilly, 1994).

\section{Nuclease activity assay}

The nuclease activity assay employed was similar to that described for use with rat thymocytes (Montague et al, 1997). In brief, granulosa cells were harvested from eCG-primed rat ovaries (see 'Granulosa cell isolation' above), from which nuclei were isolated by using a Kontes Glass homogenizer (see 'Cell-free nuclear autodigestion assays' above). Nuclear extracts were prepared by freeze-thawing isolated nuclei in Tris- $\mathrm{HCl} / \mathrm{CaCl}_{2} / \mathrm{MgCl}_{2}$ buffer followed by a $37^{\circ} \mathrm{C}$ incubation for $30 \mathrm{~min}$. Debris and chromatin were pelleted by ultracentrifugation $(100000 \times g)$ for $30 \mathrm{~min}$ at $4^{\circ} \mathrm{C}$, and the resultant supernatant containing nuclear proteins was collected and assessed for protein content. To test for nuclease activity (see Montague et al, 1997), the pUC18 plasmid (Stratagene, La Jolla, CA, USA) was linearized with the Smal restriction enzyme and added to tubes $(1 \mu \mathrm{g} /$ reaction) containing $3 \mu \mathrm{g}$ of GC nuclear protein extract without or with vehicle or protease inhibitors (SAM, $1 \mathrm{mM} ; \mathrm{DCl}, 0.5$ or $1 \mathrm{mM}$ ) in a total volume of $10 \mu \mathrm{l}$ (in $50 \mathrm{mM}$ Tris- $\mathrm{HCl}, 1 \mathrm{mM} \mathrm{MgCl}, 1 \mathrm{mM} \mathrm{CaCl}$ ). Samples were incubated for $1.5 \mathrm{~h}$ at $37^{\circ} \mathrm{C}$, after which $20 \mu \mathrm{g}$ of proteinase-K $(1 \mu \mathrm{l}$ of a $20 \mathrm{mg} / \mathrm{ml}$ stock) were added followed by an additional incubation at $55^{\circ} \mathrm{C}$ for $1 \mathrm{~h}$. Samples were then resolved through $1.0 \%$ agarose gels $(1.5 \mathrm{~h}, 80 \mathrm{~V})$, stained with ethidium bromide, and visualized by UV transillumination.

\section{Data analysis and presentation}

All experiments were repeated at least three times. For qualitative analysis, a representative autoradiogram or photograph (derived from results of at least three independent experiments) is presented in the Results section where appropriate. Quantitative results obtained from $\beta$-counting of low MW DNA fragments (oligonucleosomal DNA analysis) represent the mean \pm S.E.M. of combined data from the replicate experiments. Statistical differences between mean values were analyzed by one-way analysis of variance followed by Scheffe's test, and significance was assigned at $P<0.05$.

\section{Acknowledgements}

This study was supported by grants to JLT from the United States National Institute of Child Health and Human Development (R01HD34226), National Institute on Aging (R01-AG12279) and National Institutes of Health Office of Research on Women's Health. K Kugu is on leave from the Department of Obstetrics and Gynecology, The University of Tokyo, Faculty of Medicine, Tokyo 113, Japan. AM Trbovich and FM Hughes $\mathrm{Jr}$ contributed equally to this work. This work described is in partial fulfilment of the requirements for Doctoral studies of AMT at the Boston University School of Medicine, Department of Pathology and Laboratory Medicine (Boston, Massachusetts, USA). GI Perez is a Postdoctoral Research Fellow supported in part by a grant from the Massachusetts General Hospital Fund for Medical Discovery.

\section{References}

Alnemri ES, Livingston DJ, Nicholson DW, Salvesen G, Thornberry NA, Wong WW and Yuan J (1996) Human ICE/CED-3 protease nomenclature. Cell 87: 171

Birren B and Lai E (1993) Pulsed field gel electrophoresis: a practical guide. (San Diego: Academic Press)

Casciola-Rosen LA, Miller DK, Anhalt GJ and Rosen A (1994) Specific cleavage of the $70-\mathrm{kDa}$ protein component of the $\mathrm{U} 1$ small nuclear ribonucleoprotein is a characteristic biochemical feature of apoptotic cell death. J. Biol. Chem. 269: 30757-30760

Chinnaiyan AM, Orth K, O'Rourke K, Duan H, Poirier GG and Dixit MM (1996) Molecular ordering of the cell death pathway. $\mathrm{Bcl}-2$ and $\mathrm{Bcl}-\mathrm{x}_{\mathrm{L}}$ function upstream of the CED-3-like apoptotic proteases. J. Biol. Chem. 271: 4573-4584

Chow SC, Weis M, Kass GEN, Holmström TH, Eriksson JE and Orrenius S (1995) Involvement of multiple proteases during Fas-mediated apoptosis in $\mathrm{T}$ lymphocytes. FEBS Lett. 364: 134-138

Chun S-Y, Billig H, Tilly JL, Furuta I, Tsafriri A and Hsueh AJW (1994) Gonadotropin suppression of apoptosis in cultured preovulatory follicles: mediatory role of endogenous insulin-like growth factor-I. Endocrinology 135: 1845-1853

Cohen GM, Sun X-M, Snowden RT, Dinsdale D and Skilleter DN (1992) Key morphological features of apoptosis may occur in the absence of internucleosomal DNA fragmentation. Biochem. J. 286: 331-334

Collins RJ, Harmon BV, Gobe GC and Kerr JFR (1992) Internucleosomal DNA cleavage should not be used as the sole criterion for identifying apoptosis. Int. J. Rad. Biol. 61: 451-453

Compton MM and Cidlowski JA (1987) Identification of a glucocorticoid-induced nuclease in thymocytes. A potential 'lysis gene' product. J. Biol. Chem. 262: $8288-8292$

Ellis HM and Horvitz HR (1986) Genetic control of programmed cell death in the nematode C. elegans. Cell 44: 817-829

Estoppey S, Rodriquez I, Sadoul Rand Martinou J-C (1997) Bcl-2 prevents activation of CPP32 cysteine protease and cleavage of poly (ADP-ribose) polymerase and U1-70 kD proteins in staurosporine mediated apoptosis. Cell Death Differ. 4: $34-38$

Fernandes-Alnemri T, Litwack G and Alnemri ES (1994) CPP32, a novel human protein with homology to Caenorhabditis elegans cell death protein Ced-3 and mammalian interleukin-1 $\beta$-converting enzyme. J. Biol. Chem. 269: 3076130764

Flaws JA, DeSanti A, Tilly KI, Javid RO, Kugu K, Johnson AL, Hirshfield AN and Tilly $\mathrm{JL}$ (1995a) Vasoactive intestinal peptide-mediated suppression of apoptosis in the ovary: potential mechanisms of action and evidence of a conserved antiatretogenic role through evolution. Endocrinology 136: 4351-4359 
Flaws JA, Kugu K, Trbovich AM, Tilly KI, DeSanti A, Hirshfield AN and Tilly JL (1995b) Interleukin-1 $\beta$-converting enzyme-related proteases (IRPs) and mammalian cell death: dissociation of IRP-induced oligonucleosomal endonuclease activity from morphological apoptosis in granulosa cells of the ovarian follicle. Endocrinology 136: $5042-5053$

Fraser A and Evan G (1996) A license to kill. Cell 85: 781 -784

Gross-Bellard M, Oudet P and Chambon P (1973) Isolation of high-molecular-weight DNA from mammalian cells. Eur. J. Biochem. 36:32-38

Guthrie HD, Grimes RW, Cooper BS and Hammond JM (1995) Follicular atresia in pigs: measurement and physiology. J. Animal Sci. 73: 2834-2844

Harper JW, Hemmi K and Powers JC (1985) Reaction of serine proteases with substituted isocoumarins: discovery of 3,4-dichloroisocoumarin, a new general mechanism based serine protease inhibitor. Biochemistry 24: 1831-1841

Hengartner MO and Horvitz HR (1994) Programmed cell death in Caenorhabditis elegans. Curr. Opin. Genet. Develop. 4: 581-586

Hughes Jr FM and Gorospe WC (1991) Biochemical identification of apoptosis (programmed cell death) in granulosa cells: evidence for a potential mechanism underlying follicular atresia. Endocrinology 129:2415-2422

Hughes Jr FM and Cidlowski JA (1997) Utilization of an in vitro apoptosis assay to evaluate chromatin degradation by candidate apoptotic nucleases. Cell Death Differ. 4:200-208

Hughes Jr FM, Fong Y-Y and Gorospe WC (1994) Interleukin-6 stimulates apoptosis in FSH-stimulated rat granulosa cells in vitro: development and utilization of an in vitro model. Endocrine 2: 997-1002

Johnson AL, Bridgham JT, Witty JP and Tilly JL (1996) Susceptibility of avian ovarian granulosa cells to apoptosis is dependent upon stage of follicle development and is related to endogenous levels of $b c /-x_{\text {long }}$ gene expression. Endocrinology 137 : 2059-2066

Jolly PD, Tisdall TJ, Heath DA, Kun S and McNatty KP (1994) Apoptosis in bovine granulosa cells in relation to steroid synthesis, cyclic adenosine $3^{\prime}, 5^{\prime}$ monophosphate response to follicle-stimulating hormone and luteinizing hormone, and follicular atresia. Biol. Reprod. 51: 934-944

Kaipia A, Chun S-Y, Eisenhauer K and Hsueh AJW (1996) Tumor necrosis factor- $\alpha$ and its second messenger, ceramide, stimulate apoptosis in cultured ovarian follicles. Endocrinology 137: 4864-4870

Ko LJ and Prives C (1996) p53: puzzle and paradigm. Genes Develop. 10: 1054 1072

Korsmeyer SJ (1995) Regulators of cell death. Trends Genet. 11: 101 - 105

Kumar S (1997) The Bcl-2 family of proteins and activation of the ICE-CED-3 family of proteases: a balancing act in apoptosis? Cell Death Differ. 4: 2-3

Kumar S, Kinoshita M, Noda M, Copeland NG and Jenkins NA (1994) Induction of apoptosis by the mouse Nedd 2 gene which encodes a protein similar to the product of the $C$. elegans cell death gene ced-3 and the mammalian IL-1 $\beta$ converting enzyme. Genes Dev. 8: 1613-1626

Kumar S and Lavin MF (1996) The ICE family of cysteine proteases as effectors of cell death. Cell Death Differ. 3: 255-267

Kumar S, Tomooka Y and Noda M (1992) Identification of a set of genes with developmentally down-regulated expression in the mouse brain. Biochem. Biophys. Res. Commun. 185: 1155-1161

Luciano AM, Pappalardo A, Ray C and Peluso JJ (1994) Epidermal growth factor inhibits large granulosa cell apoptosis by stimulating progesterone synthesis and regulating the distribution of intracellular free calcium. Biol. Reprod. 51: $646-$ 654

Maravei DV, Trbovich AM, Perez GI, Tilly KI, Talanian RV, Banach D, Wong WW and Tilly JL (1997) Cleavage of cytoskeletal proteins by caspases during ovarian cell death: evidence that cell-free systems do not always mimic apoptotic events in intact cells. Cell Death Differ. 4: (in press)

Martin SJ and Green DR (1995) Protease activation during apoptosis: death by a thousand cuts? Cell 82: $349-352$

Martin SJ, O'Brien GA, Nishioka WK, McGahon AJ, Mahboubi A, Saido TC and Green DR (1995) Proteolysis of fodrin (non-erythroid spectrin) during apoptosis. J. Biol. Chem. 270:6425-6428

Martin SJ, Amarante-Mendes GP, Shi L, Chuang T-H, Casiano CA, O'Brien GA, Fitzgerald P, Tan EM, Bokoch GM, Greenberg AH and Green DR (1996) The cytoxic cell protease granzyme-B initiates apoptosis in a cell-free system by proteolytic processing and activation of the ICE/CED-3 family protease, CPP32, via a novel two-step mechanism. EMBO J. 15:2407-2416
MacDonald RG and Cidlowski JA (1981a) Glucocorticoid regulation of two serine hydrolases in rat splenic lymphocytes in vitro. Biochem. Biophys. Acta 678: 18

MacDonald RG and Cidlowski JA (1981b) Glucocorticoid-stimulated protein degradation in lymphocytes: quantitation by sodium dodecyl sulfatepolyacrylamide gel electrophoresis. Arch. Biochem. Biophys. 212: 299-410

Miller DK, Calaycay JR, Chapman KT, Howard AD, Kostura MJ, Molineaux SM and Thornberry NA (1993) The IL-1 $\beta$ converting enzyme as a therapeutic target. Ann. N.Y. Acad. Sci. 696: 133-148

Montague JW, Hughes Jr FM and Cidlowski JA (1997) Native recombinant cyclophilins A, B and C degrade DNA independently of peptidylpropyl cis-trans isomerase activity: potential role of cyclophillins in apoptosis. J. Biol. Chem. 272: 6677-6684

Nicholson DW, Ali A, Thornberry NA, Vaillancourt JP, Ding CK, Gallant M, Gareau Y, Griffin PR, Labelle M, Lazebnik Y, Munday NA, Raiu SM, Smulson ME, Yamin T-T, Yu VL and Miller DK (1995) Identification and inhibition of the ICE/CED-3 protease necessary for mammalian apoptosis. Nature 376: $37-43$

Oberhammer F, Wilson JW, Dive C, Morris ID, Hickman JA, Wakeling AE, Walker PR and Sikorska M (1993) Apoptotic death in epithelial cells: cleavage of DNA to 300 and/or $50 \mathrm{~kb}$ fragments prior to or in the absence of internucleosomal fragmentation. EMBO J. 12: 3679-3688

Patel T, Gores GJ and Kaufmann SH (1996) The role of proteases during apoptosis. FASEB J. 10: $587-597$

Perry DK, Smyth MJ, Wang H-G, Reed JC, Poirier GG, Obeid LM and Hannun YA (1997) Bcl-2 acts upstream of the PARP proteases and prevents its activation. Cell Death Differ. 4: 29-33

Powers JC and Harper JW (1986) Inhibitors of serine proteinases. In Proteinase inhibitors, In Barrett AJ and Salvensen, eds (Amsterdam: Elsevier Science Publishers) pp 55-152

Reed JC (1994) Bcl-2 and the regulation of programmed cell death. J. Cell Biol. 124: $1-6$

Schwartzman RA and Cidlowski JA (1991) Internucleosomal deoxyribonucleic acid cleavage activity in apoptotic thymocytes: detection and endocrine regulation. Endocrinology 128: 1190-1197

Shimizu T and Pommier Y (1996) DNA fragmentation induced by protease activation in p53-null human leukemia HL60 cells undergoing apoptosis following treatment with the topoisomerase I inhibitor camptothecin: cell-free system studies. Exp. Cancer Res. 226: 292-301

Squier M, Miller A, Malkinson A and Cohen J (1994) Calpain activation in apoptosis. J. Cell. Physiol. 159: 229-237

Suffys P, Beyeart R, Roy FV and Fiers W (1988) Involvement of a serine protease in tumour necrosis factor mediated cytotoxicity. Eur. J. Biochem. 178: 257-265

Tewari M, Quan LT, O'Rourke K, Desnoyers S, Zeng Z, Beilder DR, Poirier GG, Salversen GS and Dixit VM (1995) Yama/CPP32 $\beta$, a mammalian homolog of CED-3, is a crmA-inhibitable protease that cleavage the death substrate poly(ADP-ribose) polymerase. Cell 81: 801-809

Thornberry NA, Bull HG, Calaycay JR, Chapman KT, Howard AD, Kostura MJ, Miller DK, Molineaux SM, Weidner JR, Aunins J, Elliston KO, Ayala JM, Casano FJ, Chin J, Ding GJ-F, Egger LA, Gaffney EP, Limjuco G, Palyha OC, Raju SM, Rolando AM, Salley JP, Yamin T-T, Lee TD, Shively JE, MacCross M, Mumford RA, Schmidt JA and Tocci MJ (1992) A novel heterodimeric cysteine protease is required for interleukin-1 $\beta$ processing in monocytes. Nature 356: 768-774

Tilly JL (1993) Ovarian follicular atresia: a model to study the mechanisms of physiological cell death. Endocrine J. (Endocrine) 1:67-72

Tilly JL (1994) Use of the terminal transferase DNA labeling reaction for the biochemical and in situ analysis of apoptosis. In Cell biology: a laboratory handbook, in Celis JE, ed. (San Diego: Academic Press) pp. $330-337$

Tilly JL (1996) Apoptosis and ovarian function. Rev. Reprod. 1: 162-172

Tilly JL and Hsueh AJW (1993) Microscale autoradiographic method for the qualitative and quantitative analysis of apoptotic DNA fragmentation. J. Cell. Physiol. 154: 519-526

Tilly JL and Ratts VS (1996) Biological and clinical importance of ovarian cell death Contemp. Obstet. Gynecol. 41: 59-86 
Tilly JL and Tilly KI (1995) Inhibitors of oxidative stress mimic the ability of folliclestimulating hormone to suppress apoptosis in cultured rat ovarian follicles. Endocrinology 136: 242-252

Tilly JL, Kowalski KI, Johnson AL and Hsueh AJW (1991) Involvement of apoptosis in ovarian follicular atresia and postovulatory regression. Endocrinology 129: $2799-2801$

Tilly JL, Kowalski KI, Schomberg DW and Hsueh AJW (1992a) Apoptosis in atretic ovarian follicles is associated with selective decreases in messenger ribonucleic acid transcripts for gonadotrophin receptors and cytochrome P450 aromatase. Endocrinology 131: 1670-1676

Tilly JL, Billig H, Kowalski KI and Hsueh AJW (1992b) Epidermal growth factor and basic fibroblast growth factor suppress the spontaneous onset of apoptosis in cultured rat ovarian granulosa cells and follicles by a tyrosine kinase-dependent mechanism. Mol. Endocrinol. 6: 1942-1950

Tilly JL, Tilly KI, Kenton ML and Johnson AL (1995a) Expression of members of the $b c l-2$ gene family in the immature rat ovary: equine chorionic gonadotropinmediated inhibition of apoptosis is associated with decreased bax and constitutive $b c l-2$ and $b c l-x_{\text {long }}$ messenger ribonucleic acid levels. Endocrinology 136: $232-241$

Tilly JL, Flaws JA, DeSanti A, Kugu K, Rubin JS and Hirshfield AN (1995b) Role of intrafollicular growth factors in maturation and atresia of rat ovarian follicles. Biol. Reprod. 52 (Supplement 1): 159

Tilly KI, Banerjee S, Banerjee PP and Tilly JL (1995c) Expression of the p53 and Wilms' tumor suppressor genes in the rat ovary: gonadotropin repression in vivo and immunohistochemical localization of nuclear p53 protein to apoptotic granulosa cells of atretic follicles. Endocrinology 136: 1394-1402

Tilly JL, Flaws JA, DeSanti AM, Hughes FM Jr, Tilly KI, Maravei DV, Trbovich AM, Cidlowski JA and Hirshfield AN (1996) Biochemical and morphological investigation of apoptosis and atresia in rat ovarian antral follicles incubated in vitro. Biol. Reprod. 54 (Supplement 1): 87

Tilly JL, Tilly KI and Perez GI (1997) The genes of cell death and cellular susceptibility to apoptosis in the ovary: a hypothesis. Cell Death Differ. 4: 180-187

Walker PR and Sikorska M (1994) Endonuclease activities, chromatin structure, and DNA degradation in apoptosis. Biochem. Cell Biol. 72: 615-623
Walker PR, Weaver VM, Lach B, LeBlanc J and Sikorska M (1994) Endonuclease activities associated with high molecular weight and internucleosomal DNA cleavage in apoptosis. Exp. Cell Res. 213: 100-106

Walker PR, Pandey S and Sikorska M (1995) Degradation of chromatin in apoptosis. Cell Death Differ. 2: 97-104

Wang L, Miura M, Bergeron L, Zhu H and Yuan J (1994) Ich-1, an ICE/ced-3-related gene, encodes both positive and negative regulators of programmed cell death. Cell 78: 739-750

Weaver VM, Lach B, Walker PR and Sikorska M (1993) Role of proteolysis in apoptosis: involvement of serine proteases in internucleosomal DNA fragmentation in immature thymocytes. Biochem. Cell Biol. 71: 488-500

Weis M, Schlegel J, Kass GEN, Holmström TH, Peters I, Eriksson J, Orrenius S and Chow SC (1995) Cellular events in Fas/APO-1-mediated apoptosis in JURKAT T lymphocytes. Exp. Cell Res. 219: 699-708

Wilson KP, Black JF, Thomson JA, Kim EE, Griffin JP, Navia MA, Murcko MA Chambers SP, Aldape RA, Raybuck SA and Livingston DJ (1994) Structure and mechanism of interleukin- $1 \beta$ converting enzyme. Nature 370: 270-275

Wyllie AH (1995) The genetic regulation of apoptosis. Curr. Opin. Genetics Dev. 5 : 97-104

Xue D, Shaham S and Horvitz HR (1996) The Caenorhabditis elegans cell-death protein CED-3 is a cysteine protease with substrate specificities similar to those of the human CPP32 protease. Genes Develop. 10: 1073-1083

Yang E and Korsmeyer SJ (1996) Molecular thanatopsis: a discourse on the BCL-2 family and cell death. Blood 88: 386-401

Yuan J, Shaham S, Ledoux S, Ellis HM and Horvitz HR (1993) The C. elegans death gene ced-3 encodes a protein similar to mammalian interleukin- $1 \beta$-converting enzyme. Cell 75: 641-752

Zakeri Z, Quaglino D, Latham T and Lockshin RA (1993) Delayed internucleosoma DNA fragmentation in programmed cell death. FASEB J. 7: 470-478

Zeleznik AJ, Ihrig L and Bassett SG (1989) Developmental expression of a $\mathrm{Ca}^{++}$/ $\mathrm{Mg}^{++}$-dependent endonuclease activity in rat granulosa and luteal cells. Endocrinology 125: 2218-2220 